\title{
The Question of the Armenian Genocide in Taner Akçam's Intrpretation
}

\author{
Seda Gasparyan \\ Yerevan State University
}

\begin{abstract}
The present paper aims to reveal the standpoint of the Turkish scholar Taner Akçam in the recognition and condemnation of the Armenian Genocide. The linguistic approach to the study of his considerations of the question, as well as his firm belief concerning the responsibility of the present Turkish government for the shameful actions of their predecessors helps to bring out interesting facts and implied meanings.
\end{abstract}

Key words: the Armenian Genocide, shameful facts, face one's history, recognize and condemn, responsibility.

\section{Introduction}

In recent years a unique link in the chain of Western scholarly comments on the recognition and condemnation of the Armenian Genocide is the book $A$ Shameful Act: The Armenian Genocide and the Question of Turkish Responsibility authored by Taner Akçam, a Turkish historian and sociologist ${ }^{1}$ who openly criticizes the 1915 felony qualifying it as a genocide ${ }^{2}$. In the book, the history of the Armenians of the Ottoman era and the Armenian-Turkish relations in general are examined in a new light, "breaking" many ideological cliches and stereotypes. Based on thorough investigation this book by T. Akçam presents to the current generation of Turks the shameful facts of their past. The author hopes that Turkey will one day face its own history and bear moral responsibility for the Armenophobic policy of its ancestors. This is the decisive step Turkey must take paving the way to real democracy. 


\section{T. Akçam: Attitudes and Estimations}

T. Akçam's position in the issue of the Armenian Genocide becomes obvious at the very moment one takes the book in hand. The title itself succinctly discloses the author's evaluative attitude to the facts, events and conceptions presented. His denouncing approach first of all is indicated in the attributive word combination a shameful act in the title, the basic semantic unit being the attribute expressed by the adjective shameful; the idea of shamefulness is being actualized by the stem shame carrying an intrinsically negative connotational colour combined with the suffix -ful, which is meant to make the negative colouring even stronger. The inherent negative charge of the unit shameful becomes even more intensified when perceived in the context of the Armenian Genocide and the question of Turkish responsibility where the unquoted use of the unit genocide directly points to the fact that the author actually admits the reality of the Armenian Genocide and condemns its executors. Moreover, T. Akçam's ethnic identity is no obstacle on his way to expressing his honest views in defence of the Armenian cause and calling on his fellow nationals not to shirk responsibility, for only by taking the responsibility may they try to cleanse the brand of shame inherited from their ancestors.

Thus, the very title of the book attracts the reader's attention and succinctly informs about the overall content of the narrative, discloses the identity of the text in general and enables the reader to foresee the author's predisposition.

In his book T. Akçam covers a large range of questions elucidating the genocidal situation in the Ottoman Empire at the beginning of the 20th century. He presents, describes and discusses completely fresh and crucially important records and facts the investigation of which leaves no room for doubts about a centrally planned and instructed operation of annihilation and even the division of labour among various organizations.

Discussing the causes of the Genocide the author, referring to Ahmed Refik, highlights the documented reality that the annihilation of Armenians had long become one of the national objectives of the Unionist leaders who had planned to avoid carrying out reforms in the six eastern provinces, and to solve the Armenian "problem" at its root (p. 112). 
On the other hand he reveals the falsity of the prevailing opinion of Turkey's forced entrance into the war. As the author confirms, the Unionists, on the contrary, made great efforts to join the war, for they were well aware of the opportunities they could be availed of by the process of World War I. They expected they could manage to return the territories lost in the Balkan war and accomplish their grand project of Pan-Turanist and Pan-Islamic expansion.

Referring to different documents, official and private correspondence $\mathrm{T}$. Akçam also brings out the ideal of the Turkish authorities to destruct the Moscovite enemy in order to get a possibility to include all branches of Turkic people into the Empire and unite them. The author criticizes the "illusory goal" of the Ottomans which prompted them to instigate the actions in Baku in 1918 aimed at cleansing Azerbeijan of Russians and Armenians in order to provide "territorial continuity" between Turks. ${ }^{3}$

Thus T. Akçam openly declares that the Turkish authorities perceived Armenians (as well as Greeks) to be a major territorial and religious obstacle preventing the realization of their Pan-Islamic objectives. This was a goal which they strived to achieve by all means: deportations, mass killings, violation of historical, geographical and demographic facts.

Interestingly enough, the author dedicates his book to the memory of an ethnic Turk, named Haji Halil, who (as testified by Greg Sarkisyan at a conference in Armenia in 1995), risking his own life, saved and hid eight members of the family of Greg Sarkisyan's mother for more than six months. The author believes this heroic deed of Haji Halil, as well as the candid praise for the act of a Turk by Armenians makes him expect positive shifts in Armenian-Turkish relations. Thus:

I would like to dedicate this book to the memory of Haji Halil, a devout Muslim Turk, who saved the members of an Armenian family from deportation and death by keeping them safely hidden for over half a year, risking his own life. His courageous act continues to point the way toward a different relationship between Turks and Armenians...<... I was deeply moved by the story, by 
the humanity that triumphed over evil and by the fact that an Armenian could find it in his heart to praise a Turk in a public forum, for the humanity. The memory of Haji Halil reminds us that both, Turks and Armenians, have a different history on which they can build a future.

It is rather obvious from the context of the passage that, writing on the Armenian Genocide and commemorating an ethnic Turk, the author aims at opening the eyes of the Turkish society, help them know and understand their past, thus attempting to shed new light on the Armenian-Turkish relations. And although the author fully reasons that the heroic stance of Haji Halil and other individuals alike cannot level out the amount of what had been done and the grade of the atrocities, he cannot underestimate the value of this kind of Turk. He would prefer more people among his nation be like Haji Halil, for Akçam is also a Turk, and he does not want to be ashamed for the disgraceful behaviour of his compatriots.

This book breaks with that tradition. It is a call to the people of Turkey to consider the suffering inflicted in their name on those "others". The reason for this call is not only the scale of the Armenian genocide, which was in no way comparable to the individual acts of revenge carried out against Muslims. It is also because all studies of large-scale atrocities teach us one core principle: to prevent the recurrence of such events, people must first consider their own responsibility, discuss it, debate it, and recognize it. In the absence of such honest consideration, there remains the high probability of such acts being repeated, since every group is inherently capable of violence; when the right conditions arise this potential may easily become reality, and on the slightest of pretexts. There are no exceptions. Each and every society needs to take a self-critical approach, one that should be firmly institutionalized as a community's moral tradition regardless 
of what others might have done to them. It is this that prevents renewed eruptions of violence.

This book is an appeal to the Turkish people not to evade reviewing the shameful chapters of their history full of atrocities, but rather to make an effort to discuss, learn and criticize the condemnable acts of Turks in order to prevent such crimes against humanity in future. In the passage this idea is conveyed to the reader by the use of such connotationally coloured linguistic means as inflict, prevents, renewed, eruptions, violence.

From a pragmalinguistic viewpoint ${ }^{4}$ the use of homogeneous predicates (people must consider their own responsibility, discuss it, debate it, recognize it) is of special interest; hereby the author tries not only to make his language more persuasive but also denote the sequence of steps that may bring to the admittance of the Genocide: first, consider their share of guilt, discuss, debate and then recognize. From the pragmatic point of view the use of the unit "others" is also important. In our surveys we have dealt with the use of pronominal units their, they, these in works that deny and reject the fact of the Armenian Genocide. Particularly in the book titled "An Armenian Question...? Let's Consider..." by H.B. Danisman, the unquoted use of pronominal units expresses the implicit sense of mutual alienation and hostility. ${ }^{5}$ In the example above the quoted pronoun "others" emphasizes the fervent desire of the author to eliminate the stereotype of mutual alienation, in the meantime targeting his criticism against scholars who accept, confirm and constantly fuel the sense of alienation by using quotation marks. In other words, the quotations in this case give a new meaning to the word fulfilling its communicative purpose: to highlight the idea of peaceful coexistence of nations, including Armenians and Turks.

By dedicating his book to the memory of Haji Halil the author writes about the Genocide of Armenians, admitting and recognizing it, but at the same time as an ethnic Turk he seeks to somehow justify the Turkish people by refusing to make generalizations about the Turkish society as a whole. The use of words, collocations and utterances like every group, inherently capable of violence, the 
right conditions arise this potential may easily become reality, on the slightest of pretexts affirms this not only in the given passage but also in other extracts of the book like the one that follows:

Those who acted collectively in history were not the entirety of "Turks" and "Armenians", but certain organizations or groups that shared a common interest and claimed to be acting in the name of the nation or religion to which they belonged. In some cases, this meant the government; in others a political party; in still others, the representatives of a clearly defined class or subclass. It is even questionable whether the broad mass of Muslims in Anatolia at the time understood themselves as Turks, or Kurds, rather than as Muslims. In all cases, however, these actors never comprised the entire national or religious group that they claimed to represent.

The first thing in the passage that strikes the attention of the reader is the statement of the author which indirectly guestions the awareness of Turks and Kurds of their national identity (whether the broad mass of Muslims in Anatolia at the time understood themselves as Turks, or Kurds, rather than as Muslims) and spreads light on what R. Suny tries hard to disguise under the veil of World War I. That is the basic underlying reason for pre-planning and unleashing the Armenian Genocide - the insatiable desire of the Turkish authorities to take possession of vast territories in the Middle East and establish the Greater Turan inhabited only by Muslim population (cf. pp. 79, 85, 90,91 of the present book). Thus, it was their aspiration for religious superiority and the morbid pining for the Greater Turan that mattered, and this can be deduced from the mentioned utterance of the passage. Although in various parts of the narrative the author emphasizes the fact of the pre-planned nature of the Armenian Genocide, based on the documentary files of numerous testimonies, court writs, national and international instructions, published and unpublished notes and memorandums, nevertheless, by using words and expressions like group, government, organization, political party, representatives of a clearly defined class or 
subclass the author once again attempts to persuade the reader that the committed crime was the act of a specific group - a political party, authorities or some other team. And he does this with a sole purpose: to alleviate the share of guilt of the Turkish people trying to enhance the idea that not the nation as a whole but a certain group of people is to be held culpable.

The following passage where the author examines the terms "Armenian" and "Turk" makes this notion even more convincing:

...Instead I have selected more precise terms for the people involved in any particular actions. The terms "Turks" and "Armenians" which are widely used in historiography and conversation, are not historical categories but rather ahistorical constructions. They are used to express only that one group is not Armenian and the other not Turk. This not only misrepresents history but exacerbates public perceptions and prejudices today.

The passage reveals the author's intention: to take a fresh look at the terms "Armenian" and "Turk," and bring the discussion of the Armenian-Turkish relationship to a new stage. One can hardly accept the author's idea of the terms "Armenian" and "Turk" being non-historical categories. As words widely used in historical, ethnographical and anthropological studies they are merely metalinguistic units (ethnonemes) denoting ethnic identity, nevertheless, from the point of view of their conceptual content they cannot evade historicity, for ethnos itself is a community of people sharing common material, linguistic and cultural features. It is historically formed within a certain space and time ${ }^{6}$. By viewing these notions as "ahistorical" concepts the author definitely intends to take away the historically formed stereotype of alienation. However, it is undeniable that almost a century after the Genocide the words "Armenian" and "Turk" still bear a conflicting mark in both Armenian and Turkish comprehension (cf. the next chapter of the present book), also due to the fact that the culpable side is not courageous enough to admit the historical truth. Moreover, they make every possible effort to deny the undeniable truth and 
present a distorted past to their future generations. To illuminate the idea let us just refer to Taner Akçam's highlight of the term genocide.

Because of the long-standing Turkish policy of denial, the very term "genocide" has become contested - sacred to Armenians, taboo to Turks. Both sides attach supreme importance to the question whether or not "genocide" should be used.

It is not difficult to deduce from the context of the passage that the unit genocide, the use of which is definitely conditioned by the historical reality, the basic background ideology and the aim of communication, is perceived as two conflicting concepts in the minds of an Armenian and of a Turk: sacred for the Armenian, and taboo for the Turk.

Thus, in the mind of a Turkish speaker/listener the word genocide is associated with forbidden, far-fetched, silenced, immemorable and discrediting ideas which remind one of a disgraceful past, but in the mind of an Armenian it recollects a combination of the following associations: crime, massacre, tragic chapters of history, bleeding wound, dispossession of homeland, blood-shed, etc. From the perspective of a national mentality the coded meaning of the unit genocide draws the listener's attention to the connotational colouring of the word corresponding to the mindset of that very nation. In the mindset of a Turkish speaker and of an Armenian speaker the possible associations of the term genocide are not of a common nature. This explains the impossibility of mutual understanding of the issue in question between the two nations to this day. Moreover, the existing tension between the opposing sides becomes intractable as it is impossible to find common ground. It is also important that on a rational level the speaker's perception conditioned by national identity, ideology, mentality and other factors in the case of Armenians comes close to the essence of the concept of genocide and suggests ideas of requisitioning; in the case of Turks the perception drifts away from this understanding in favour of a denialist's viewpoint. 
T. Akçam's interpretation of the concept genocide is based on the definition by R. Lemkin.

I have used the term in line with the United Nations definition adopted in 1948. Accordingly, genocide includes the partial or complete destruction of an ethnic, national, racial, or religious group, whether in periods of peace or war. The definition covers various means of destruction, be it killing members of a particular group, exposing them to grave physical or emotional harm, inflicting such physical damage that ends the group's continued existence, preventing the group's members from giving birth, or forcibly removing their children and merging them with other communities. Under the terms of the UN definition, and in light of all the documentary evidence, we cannot but call the acts against the Armenians genocide.

The value of the words we cannot but call the acts against the Armenians genocide by $\mathrm{T}$. Akçam cannot be overestimated. Inspiring confidence and encouragement, they once again assert that what happened to Armenians in the Ottoman Empire at the beginning of the 20th century is nothing but genocide; and no other term but genocide could be the internationally accepted term to evaluate the committed felony.

However, a notable consideration occurs in T. Akçam's book: the author believes it is not the term itself that requires attention but the very fact of the Genocide that deserves condemnation (the moral position that recognizes the crime and condemns it).

The important thing, however, is not the term, but rather the moral position that recognizes the crime and condemns it. However we define it, whatever word we use, we must acknowledge that this history involved the deliberate destruction of a people. In 1915 Cerkez Hasan was an Ottoman officer 
commissioned to resettle Armenians in what are now the Syrian and Iraqi deserts. When he realized that the real aim of the deportations was not resettlement but annihilation he resigned. "You may argue whether or not the word 'killing' is synonymous with 'deportation'," he said. "Use it in any way you want; it doesn't change what actually happened in any real sense...There is only one terrible way to understand what happened, and of which the whole world is aware (Aksin 1987: 16999)."

One cannot possibly overlook, however, the well-established linguistic reality that any word, under the influence of various linguistic and extra-linguistic factors, can grow more powerful and capacious, can be enriched by new shades of meaning, evaluative-attitudinal components, thus changing in depth and volume, and expressing the speaker's attitude to a certain issue, turn to a weapon to influence the audience. Neither should it be ignored that each year on April 24 Armenians worldwide listen closely to the words of the President of the USA to hear whether or not he will pronounce the word genocide in his annual address, for the mere utterance of this single linguistic unit is sure to add a new subtext to the message, even to landmark a breakthrough along the process of admitting, condemning and conceding the responsibility of Turkey for the 1915 Genocide. After all why not call it what it is?

\section{Conclusion}

The Armenian Genocide must be condemned by the whole world as the first genocide of the 20th century for this is the demand of Justice, and the demand of our concern for the Future of this world; for it is our sacred duty to prevent any recurrence of genocide on this planet in future.

T. Akçam's work enables us to mark a step forward along that path, for it reassures and fosters the hope that Turkey will eventually come to read the dark chapters of its history, admit the truth, and undertake a roadmap of peace in its relations with Armenia. ${ }^{10}$ 


\section{Notes and References:}

1. Taner Akçam has been in politics since his young age. In 1976 he was arrested as an editor of a student political paper and sentenced to 10 years of imprisonment. A year later he escaped from jail and found refuge in Germany under the protection of Amnesty International. Beginning from 1988, Akçam was working at the Hamburg Social Studies Institute taking special interest in problems of the Armenian Genocide. In 1996, he defended a $\mathrm{PhD}$ thesis on the issue, and since 2002 he is an adjunct professor at the Minnesota University (USA). He is the author of 10 books including $A$ Shameful Act: The Armenian Genocide and the Question of Turkish Responsibility, published in 2006 (New York, Metropolitan Books, Henry Holt And Company), which is here the subject of our inquiry.

2. Cf. Gasparyan, S.; Harutyunyan, G. (2012) Taner Akchami "Amotali arark...” ashkhatutyuny. // Vem. Pan-Armenian Journal, No 2 (38), pp. 125-134. Yerevan: Vem Ltd.

3. Cf. Landau, J.M. (1995) Pan-Turkism: from Irredentism to Cooperation. p. 55. Blooming ton: University of Indiana Press.

4. In linguistic research nowadays more significance is being given to the role of a human being as the key element of communication. The complex relationship between the speaker/writer and the listener/reader is rendered paramount importance to in speech activity which is always dependent on the pragmatic goal of the speaker. Thus, pragmalinguistics - an appealing and promising branch of linguistics, is always communicatively-oriented and aims at revealing the peculiar features of speech formation in this or that social and communicative situation. Cf. Levinson, S.C. (1983) Pragmatics. Cambridge: CUP; Arutyunova, N.D.; Paducheva, Y.V. (1985) Istoki, problemy i kategoii pragmatiki . // Novoe v zarubezhnoy lingvistike, vyp. 16. M., izd.-vo Progress, s. 3-43; Verschueren, J. (1999) Understanding Pragmatics. London, New-York: OUP, etc.

5. Gasparyan S.; Harutyunyan, G.; Gasparyan, L. (2011) Interpretations of the Armenian Genocide: A Linguocognitive Study. // "Language, Literature \& 
Art in Cross-Cultural Contexts," AASE-3 International Conference. Yerevan, 2011, 4-8 October.

6. Cf. Pilisopayakan bararan (1975) Yerevan, Armenia Press, p. 4. This is particularly supported by Miroslav Hroch (1996) in his essay Nationalism and National Movements: comparing the past and the present of Central and Eastern Europe. // Nations and Nationalism, № 2(1), p. 35-44.

7. In 1944 the US saw the publication of Axis Rule in Occupied Europe" by R. Lemkin in which the author came up with a thorough and detailed legal analysis of the policy of the Nazi Germany during World War II. The work is also noted for the scrupulous examination and further addition to the comments on the term genocide. Available at: <http://en.wikipedia.org/wiki/ Genocide> [Accessed 15.04. 2014, 18:12].

8. For more details cf. Gasparyan, S. (2010) Yeghern bari hamarzhekutyan dashty anglerenum. // Vem. Pan-Armenian Journal, №1(29), pp. 138-148. Yerevan: Vem Ltd.

9. Aksin, S. (1987) Zhon Tyurkler Ittihat ve Teraki. s. 169, İstanbul.

10. It is not a mere chance that T. Akçam writes: "The Armenian Genocide is nothing else but a real genocide, and not a mere massacre or murder. I would say if what happened in 1915 is not called a genocide, then we should say no genocide has ever occurred in the world." This is the rationale of the author: things must be called by their names proper to create a right attitude towards them. Available at: <http://araxmag.blogspot.com/2010/06/1915.html $\geq$ [Accessed March 2014]

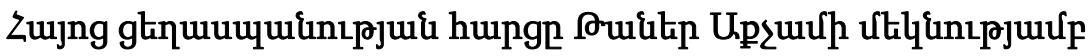

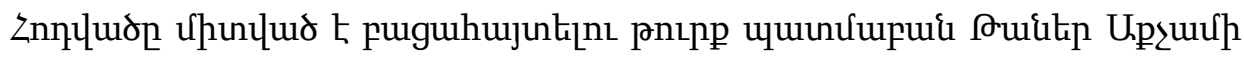

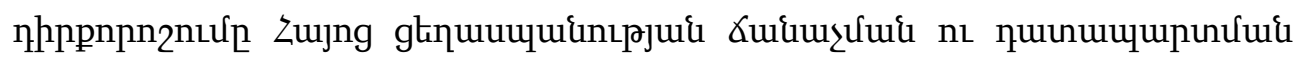

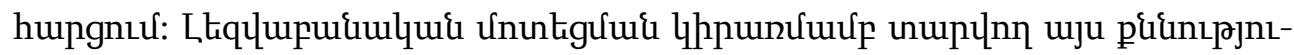

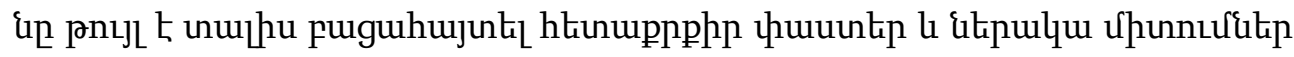

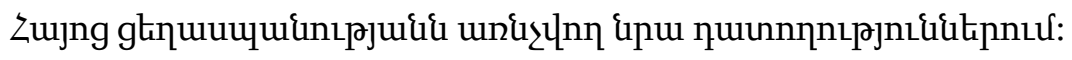

